\title{
Electron Microscopy Studies on the Immobilization Antigens of Paramecium aurelia
}

\author{
BY MARGARET R. MO'TT \\ Institute of Animal Genetics, University of Edinburgh
}

(Received 1 June 1965)

\begin{abstract}
SUMMARY
The immobilization antigens of Paramecium aurelia were located in the electron microscope by the use of antibody labelled with electron-dense ferritin. On treatment of fixed whole paramecia with ferritin-labelled antibody, followed by sectioning, ferritin granules were seen on the pellicle and cilia of homologous organisms only. By counterstaining the sections with an electron-dense stain (potassium permanganate + uranyl acetate) the absorbed globulin of the antibody was revealed as a thick fuzz on pellicle and cilia. Antigen was present over the entire surface of the organism with the exception of the gullet area. Transformation from one antigenic type to another, by change of temperature, showed the 'new' antigen to appear initially on the pellicle and subsequently on cilia. The ferritin labelling, with counterstaining, proved to be very sensitive; ferritin granules and globulin fuzz denoting 'new' antigen appearance were detected at isolated sites on the pellicle and cilia after only $1 \mathrm{hr}$ of growth at the higher temperature. The number of these sites then increased, until the granules and fuzz covered the entire surface of first the pellicle and subsequently cilia. Attempts to study the internal antigens with ferritin-labelled antibody were not successful.
\end{abstract}

\section{INTRODUCTION}

In previous papers the immobilization antigens of Paramecium were located by the use of fluorescent-labelled specific antibodies for examination under ultraviolet radiation (Coons, 1956). In the first application of this fluorescence technique to paramecium antigens (Beale \& Kacser, 1957), whole paramecia, both living and fixed, were treated with fluorescein-labelled antisera, and the immobilization antigens were shown to be present on the pellicle and cilia, with the exception of the gullet area. Later (Beale \& Mott, 1962) the interior of Paramecium was studied by treating sections of fixed organisms with antibody conjugated with either fluorescein or rhodamine. Fluorescence was observed on pellicle and cilia, and in the internal cytoplasm with the exception of the macronucleus. By pre-treating the sections with heterologous non-fluorescent antiserum, no fluorescence was observed in the cytoplasm, and fluorescence occurred only on the pellicle and cilia of homologous organisms. It was concluded that the immobilization antigens are located on the pellicle and cilia, and that the internal cytoplasmic antigens are relatively invariant in paramecia of different immobilization antigenic type. Transformation from one antigenic type to another by change of temperature, observed by using the technique of double labelling with fluorescein + rhodamine-labelled antisera, showed the 
'new' antigen to appear initially on the pellicle and subsequently on the cilia. Higher magnifications were necessary, however, to study the exact location of the immobilization antigen and other details of the membranes on which the antigen was thought to be located. This present report, therefore, covers the use of the electron microscope and ferritin, a molecule with an electron-dense core of iron surrounded by a protein shell, as the antibody level (Singer, 1959).

\section{METHODS}

The general methods used were those published by Beale \& Mott (1962).

Stocks and serotypes of Paramecium aurelia. Stock 168, variety 1, serotypes G and $\mathrm{D}$, were used. Type $168 \mathrm{G}$ is stable at $25^{\circ}$, type $168 \mathrm{D}$ at temperature above $30^{\circ}$. Transformation from type $168 \mathrm{G}$ to type $168 \mathrm{D}$ was obtained as in Beale \& Mott (1962). Samples of paramecia were taken at intervals and examined for the stage of antigenic change by three methods : (i) fixed paramecia were studied with the electron microscope and ferritin labelling; (ii) with the light microscope and fluorescent labelling, while at the same time, (iii), live samples were tested for immobilization with antisera to the initial and final antigens.

General cultivation techniques. The paramecia were grown according to the general methods of Sonneborn (1950), with dried lettuce leaf infusions and with Aerobacter aerogenes at $\mathrm{pH} 6 \cdot 8-7 \cdot 4$; this gave about 5 fissions in $24 \mathrm{hr}$.

Maintenance solution. A non-nutrient medium was used for washing the paramecia; it consisted of $0.013 \mathrm{M}-\mathrm{NaCl}, 0.0003 \mathrm{M}-\mathrm{KCl}, 0.0003 \mathrm{M}-\mathrm{CaCl}_{2}, 0.004 \mathrm{M}-\mathrm{NaK}$ phosphate buffer; $\mathbf{p H ~ 7 . ~ ( T h e ~ m o l a r i t y ~ o f ~ t h e ~} \mathrm{CaCl}_{2}$ solution was in error in Beale \& Mott, 1962.)

Preparation of antisera. Antisera were made against whole paramecia according to the method of Sonneborn (1950) by injecting homogenates of whole organisms into rabbits. The sera were incubated at $56^{\circ}$ to inactivate complement, dialysed against Maintenance Solution and stored frozen in small samples. Antisera were developed against antigens $168 \mathrm{D}$ and $168 \mathrm{G}$; and a 'heterologous' antiserum, i.e. one not reacting with the immobilization antigens $168 \mathrm{D}$ and $168 \mathrm{G}$, was developed against stock $192 \mathrm{X}$.

Preparation of fluorescent labelled antibody. A modification of the method of Coons \& Kaplan (1950) by Marshall, Eveland \& Smith (1958) was used to label antibody with fluorescein; the method of Chadwick, McEntegart \& Nairn (1958) was used to label antibody with rhodamine, as in Beale \& Mott (1962).

A preliminary brief account of the following methods was published by Mott (1963).

Preparation of ferritin-labelled $\gamma$-globulin. The $\gamma$-globulins of the antisera were precipitated by half-saturation with ammonium sulphate, the final precipitated globulins being made up in and dialysed against Maintenance Solution, to a final concentration of $20 \mathrm{mg}$. $\gamma$-globulin $/ \mathrm{ml}$. Some of this globulin from each antiserum was retained unlabelled, and the remainder labelled with ferritin. Ferritin preparations from two sources were used: the first, prepared by Dr P. M. Harrison (Department of Biochemistry, The University, Sheffield), was obtained from Dr R. M. Clayton; the second was obtained from Calbiochem, Los Angeles, California, U.S.A., as a preparation in $\mathrm{CdSO}_{4}$, crystallized $\times 6$. Ferritin was coupled to the $\gamma$-globulin by 
using the $m$-xylylene di-isocyanate bifunctional coupling agent of Singer (1959) in the improved method of Singer \& Schick (1961). The ferritin-labelled globulin was then dialysed against Maintenance Solution and centrifuged at 10,000 rev./min. for $30 \mathrm{~min}$. This gave a clear stable solution; small samples were stored frozen at $-20^{\circ}$. The loss of activity of the globulin during the conjugation procedure was about $30 \%$.

Treatment with antibody. Paramecia were gently centrifuged down, washed in Maintenance Solution, and then fixed for $30 \mathrm{~min}$, with occasional mixing, in $1 \%$ $(\mathrm{w} / \mathrm{v})$ osmic acid in 0.014 M-veronal acetate buffer of $\mathrm{pH} 7 \cdot 4$; (Palade, 1952) containing $1.3 \%$ sucrose (Caulfield, 1957). The fixed organisms were pre-treated first with unlabelled, heterologous (anti-192X) serum, diluted $1 / 2$, for $1 \mathrm{hr}$ as with the fluorescence technique, and then treated with the specific ferritin-labelled $\gamma$-globulin, undiluted, for 1-2 hr. The organisms were well washed in Maintenance Solution between procedures.

Araldite embedding and sectioning. The paramecia were dehydrated in increasing ethanol concentrations and embedded in the epoxy-resin Araldite M. (Glauert \& Glauert, 1958) using volatile 1-2 epoxy propane with the Araldite for better penetration (Luft, 1961). Sections were cut on a Porter-Blum microtome with glass knives, and were examined on grids with a supporting film of formvar and carbon.

Counterstaining the sections. Some grids were left unstained to demonstrate ferritin granules in the sections. Other sections were counterstained by floating the grids, section downwards, on a solution containing potassium permanganate and uranyl acetate, a modification of methods by Lawn (1960) and Watson (1958). The grids were floated for $20 \mathrm{~min}$. on $2.5 \%(\mathrm{w} / \mathrm{v})$ uranyl acetate in $1 \%(\mathrm{w} / \mathrm{v})$ potassium permanganate, and washed by floating on the surface of distilled water. The sections were then partly decolorized by floating, for $30 \mathrm{sec}$. only, on a dilute citric acid solution (about $1 \mathrm{ml}$. of $5 \%, \mathrm{w} / \mathrm{v}$, citric acid $+30 \mathrm{ml}$. distilled water), then again washed with distilled water.

Electron microscopy. The sections were examined in an electron microscope, using

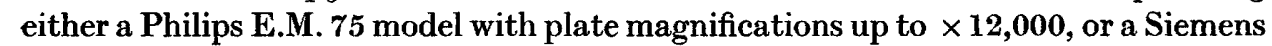
Elmiskop-I model, generally with a plate magnification of $\times \mathbf{3 0 , 0 0 0}$.

\section{RESULTS}

The specificity of the labelling techniques and the location of antigen

The osmic acid fixation did not result in loss of antigenic activity, in agreement with the earlier findings with paramecium antigens by Beale \& Kacser (1957) and with other antigens by Spendlove \& Singer (1961). Fixed whole paramecia of two different serotypes, $168 \mathrm{G}$ and $168 \mathrm{D}$, were separately treated with ferritin-labelled anti-168 D $\gamma$-globulin, after pre-treatment with heterologous unlabelled antiserum as described in Methods. After embedding in Araldite, sectioning and viewing the unstained sections under the electron microscope, ferritin granules were seen on the pellicle and cilia of homologous organisms (Pl. 1, fig. 1) but not on the non-homologous organisms. The ferritin granules (diameter about $50 \AA$ ) were only seen at high magnifications, but on counterstaining the sections with uranyl acetate + potassium permanganate, the absorbed globulin of the specific antibody was revealed even at low magnifications as a thick fuzz which covered the pellicle and cilia of homologous 
organisms. The conjugated ferritin granules were seen within this fuzz at higher magnifications, no comparable amount of fuzz being present on non-homologous organisms. This globulin fuzz was therefore of use in quickly scanning preparations at low magnifications. These findings were in accordance with those illustrated in Mott (1963).

The absence of ferritin granules and globulin fuzz from the control paramecia established the use of the technique of ferritin labelling and counterstaining for demonstrating the presence of antigen and specific antibody. By examination of many electron micrographs of the surface of paramecia by the above techniques, the immobilization antigen was found to be present over the surface of the pellicle and cilia, with the exception of the gullet area. Here the pellicle and cilia were found to have no fuzz or ferritin granules when the paramecium was treated with ferritinlabelled antibody homologous to the immobilization antigen on the rest of the organism (Pl. 1, fig. 2). It appears there are no antigens other than the immobilization antigens on the surface of paramecia, and that these cover the entire surface with the exception of the gullet area. This agreed with the findings obtained with the fluorescence technique, when paramecia treated with fluorescent antibodies to all the possible antigens (immobilizing antigens and others) showed complete lack of fluorescence in the gullet area (Beale \& Kacser, 1957).

\section{Transformation experiment type $G \rightarrow$ type $D$}

The results of taking samples of organisms at intervals and studying them simultaneously for antigenic change from type $168 \mathrm{G}$ to type $168 \mathrm{D}$ by the three series of tests (ferritin labelling, fluorescent labelling, immobilization) are shown in Table 1.

From the electron microscope study, samples of paramecia taken at the beginning of the experiment (i.e. at 'nil hours' growth at $35^{\circ}$ ) showed no ferritin granules or globulin fuzz, following treatment with ferritin-labelled anti-168D $\gamma$-globulin (Pl. 2, fig. 3). After growth at $35^{\circ}$ for only $1 \mathrm{hr}$, globulin fuzz and ferritin granules were located initially at isolated sites on the pellicle and at the proximal ends of cilia (Pl. 2, fig. 4). At this stage neither the fluorescence nor the immobilization tests gave any indication of the appearance of new antigen. By examination with the electron microscope it was seen that the antigen sites continued to increase on pellicle and cilia, and were fairly numerous after growth for $3 \mathrm{hr}$ at $35^{\circ}$. At this stage the fluorescence test was just giving faint indication of the appearance of the 'new' antigen $(168 \mathrm{D})$ on the pellicle only, while the immobilization tests still gave practically negative results. After growth for $6 \mathrm{hr}$ at $35^{\circ}$, the electron microscope showed many sites of 'new' antigen formation on pellicle and cilia, the fluorescence technique showed a fairly strongly fluorescent pellicle and faintly fluorescent cilia, and the immobilization tests now showed a very slight effect (Pl. 3, fig. 5). An organism examined under the electron microscope after $7 \mathrm{hr}$ at $35^{\circ}$ showed that the antigen $168 \mathrm{D}$ was distributed homogeneously over the pellicle, but only at isolated sites on the cilia (Pl. 3, fig. 6). At this stage the fluorescence technique showed a very strongly fluorescent pellicle and faintly fluorescent cilia, and the immobilization tests began to show some definite effect. At the final stage (18-24 hr), the fuzz and ferritin granules were seen by electron microscopy, to occur homogeneously over the entire surface of pellicle and cilia, giving the same picture as seen previously with a com- 
pletely homologous organism. Both the fluorescence and immobilization tests also showed complete change to the 'new' antigenic types.

The counterstaining of absorbed globulin proved very useful in the study of transformation of the antigens, for when transforming organisms were treated with ferritin-conjugated antibody to the 'new' antigen being formed, the successive stages could be quickly scanned for the first appearance of the globulin fuzz. This was especially so in the early stages, when little specific antigen had been formed, for the faint globulin fuzz of the antigen antibody reaction was easier to pick up than a few sparsely separated ferritin granules.

Table 1. Stages during transformation of Paramecium aurelia from antigenic type $168 \mathrm{G}$ to type $168 \mathrm{D}$ by growth at $35^{\circ}$, showing comparisons of the results by the three methods used for detecting antigen

Effect of antisera (dil. 1/50) on live organisms

\begin{tabular}{|c|c|c|c|c|c|}
\hline \multirow[b]{3}{*}{ Stage } & \multirow{3}{*}{$\begin{array}{l}\text { Time of } \\
\text { growth } \\
\text { at } \mathbf{3 5}^{\circ} \\
\text { (hr) }\end{array}$} & \multicolumn{2}{|c|}{ on live organisms } & \multirow{2}{*}{\multicolumn{2}{|c|}{$\begin{array}{l}\text { Fluorescence followin } \\
\text { treatment with } \\
\text { fluorescein-labelled } \\
\text { anti-168D serum }\end{array}$}} \\
\hline & & \multirow{2}{*}{$\begin{array}{l}\text { Anti-168G } \\
\text { immobilization } \\
\text { time } \\
\text { (min.) }\end{array}$} & \multirow{2}{*}{$\begin{array}{c}\text { Anti-168D } \\
\text { mmobilization } \\
\text { time } \\
\text { (min.) }\end{array}$} & & \\
\hline & & & & Pellicle & Cilia \\
\hline $\mathbf{0}$ & $\mathbf{0}$ & 4 & Unaffected & Nil & Nil \\
\hline 1 & 1-2 & 4 & Unaffected & Nil & Nil \\
\hline 2 & 3-5 & 4 & $\mathbf{R}$ & $\begin{array}{r}\text { *Faint } \\
\text { green }\end{array}$ & Nil \\
\hline $\mathbf{3}$ & 6 & 5 & $\mathbf{R}$ & Green & $\begin{array}{l}\text { Faint } \\
\text { green }\end{array}$ \\
\hline 4 & $7-8$ & $* 7$ & $\mathbf{R}$ & Green & Green \\
\hline 5 & 9 & 15 & 50 & Green & Green \\
\hline 6 & $18-20$ & Unaffected & 4 & Green & Green \\
\hline
\end{tabular}

\begin{tabular}{|c|c|}
\hline \multicolumn{2}{|c|}{$\begin{array}{l}\text { Ferritin granules and globulin fuzz } \\
\text { following treatment with ferritin- } \\
\text { labelled anti-168D } \gamma \text {-globulin }\end{array}$} \\
\hline \multicolumn{2}{|c|}{$\overbrace{\text { Pellicle }}^{\text {Cilia }}$} \\
\hline \multicolumn{2}{|l|}{ Nil } \\
\hline $\begin{array}{c}* \text { Granules and } \\
\text { fuzz at a few } \\
\text { isolated sites }\end{array}$ & $\begin{array}{c}\text { Granules } \\
\text { fuzz at } \\
\text { isolated }\end{array}$ \\
\hline $\begin{array}{l}\text { Sites more } \\
\text { numerous }\end{array}$ & $\begin{array}{l}\text { Sites becoming } \\
\text { more numerous }\end{array}$ \\
\hline $\begin{array}{l}\text { Sites very } \\
\text { numerous }\end{array}$ & $\begin{array}{l}\text { Sites } k \\
\text { more }\end{array}$ \\
\hline $\begin{array}{l}\text { Granules and } \\
\text { fuzz cover } \\
\text { entire surface }\end{array}$ & $\begin{array}{l}\text { Sites becoming } \\
\text { more numerous }\end{array}$ \\
\hline $\begin{array}{l}\text { Granules and } \\
\text { fuzz cover } \\
\text { entire surface }\end{array}$ & $\begin{array}{r}\text { Sites } \\
\text { nun }\end{array}$ \\
\hline $\begin{array}{l}\text { Granules and } \\
\text { fuzz cover } \\
\text { entire surface }\end{array}$ & $\begin{array}{l}\text { Granules and } \\
\text { fuzz cover } \\
\text { entire surface }\end{array}$ \\
\hline
\end{tabular}

$\mathbf{R}$ indicates retarded but not completely immobilized after $2 \mathrm{hr}$ in serum; * indicates first definite detection of change of antigen by each method.

A preliminary experiment was done by treating paramecia in the process of transformation from $168 \mathrm{G}$ to $168 \mathrm{D}$ with ferritin-labelled antibody to the antigen $168 \mathrm{G}$ initially present. After growth for $9 \mathrm{hr}$ at $35^{\circ}$, the results indicated that antigen $168 \mathrm{G}$ was still distributed fairly homogeneously over the surface of the cilia, but was present only at small isolated sites on the pellicle. At this stage the immobilization times of live organisms were much the same in antisera to each of the antigens, indicating that a fair amount of each antigen was present on the cilia.

\section{Attempts to identify intracellular antigens}

Since the ferritin labelling and counterstaining proved to be a specific and sensitive technique it was hoped to use it to examine the interior of the paramecia for the presence of immobilizing antigens. It has been shown by earlier experiments 
with whole paramecia, by using the fluorescence technique (Beale \& Kacser, 1957), that antibody does not penetrate the cell-wall. All attempts to label Araldite sections of paramecia with ferritin-labelled antibody failed, ferritin being deposited over the entire surface, as found with methacrylate sections by Baxandall, Perlmann \& Afzelius (1962). Embedding the paramecia in the water-soluble polyepoxide Durcupan (X133/2097), according to Staubli (1960) and Leduc \& Bernhard (1962), was also unsuccessful; again the ferritin was deposited non-specifically on the sections, as with Araldite.

\section{DISCUSSION}

The fine structure of the paramecium was found to be very well preserved in Araldite for electron microscope studies, especially the outer membranes, as previously noted by Stewart \& Muir (1963), since there was little polymerization damage on hardening (Glauert \& Glauert, 1958). Counterstaining of the sections with uranyl acetate + potassium permanganate was necessary, however, to bring out the fine detail of the membranes etc., because of the low contrast of embedded material in Araldite. The nature of the membranes and the general ultrastructure of the paramecium, as well as the position of the ferritin- and globulin-labelling of the antigen on the membranes, are of importance in the discussion of the possible nature of the molecular transfer in the formation of the immobilization antigen.

The following details of the general ultrastructure of the paramecium were noted. The ciliary 'corpuscle', in the terminology of Ehret \& Powers (1959), consists of the cilium, arising from the kinetosome, from the centre of the pit of the circumciliary space, the walls of which enclose the peribasal space (Pl. 2, fig. 3). The parasomal sac opens into the circumciliary space (Pl. 2, fig. 4). These ciliary corpuscles alternate with the trichocysts, and the various structures under the electron microscope make up the characteristic silver-line system of light microscopy (Pitelka, 1963). The crosssections of the cilia show the usual arrangements of nine double peripheral fibrils and two single central fibrils, with the nine secondary fibrils sometimes also visible.

The outer membranes of the paramecium consisted of two distinct membranes as previously noted (Stewart \& Muir, 1963; Mott, 1963), the outermost pellicular membrane being continuous over the entire surface of pellicle and cilia, and the inner peribasal membrane forming a continuous lining around the peribasal space (Pl. 2, fig. 3). Over the peribasal space these two membranes were separated by varying distances, the two together generally making a double membrane about $250 \AA$ wide. Both these membranes were seen to consist of the classic unit membrane, the ' 3 -ply' sheet (Robertson, 1960) about $75 \AA$ wide made up of two darkstaining outer layers each about $25 \AA$ thick, separated by a clear layer about $25 \AA$ wide, these membranes being considered to be a bimolecular leaflet of lipid covered on both sides by layers of protein (Stoeckenius, 1962). No pores were seen in these membranes, but there was frequent overlap of the membrane layers. Below the peribasal membrane, a dark-staining thick homogeneous layer or membrane was seen (Pl. 2, fig. 3), about $100 \AA$ wide, and noted previously by Pitelka (1961) in Tetrahymena; this appeared to be continuous with the septum across the base of the cilia.

The studies with ferritin labelling presented here confirm previous indications that the immobilization antigen is situated on the surface of the pellicle and cilia of the 
paramecium. From the transformation experiment, it was found that antigen appeared initially at isolated sites on pellicle and proximal ends of cilia, the number of sites gradually increasing until the antigen completely covered first the pellicle and later the cilia. Comparison of the three concurrent tests showed that the ferritinlabelling technique was much more sensitive than the fluorescent-labelling technique, both being more sensitive than the immobilization test which only reveals ciliary antigen and then only when present in fairly large amount. Stages of transformation with ferritin labelling were examined to see whether the ferritin granules, indicating 'new' antigen formation, hore any relationship to particular surface structures. No evidence was found of flow of antigen along the surface from any particular point of emergence, such as possible pores in the membranes. No pores were seen, though frequently a folding was noted (Pl. 2, fig. 3); however, the appearance of ferritin granules did not particularly coincide with any of these folds. Ferritin granules, in the transformation studies, were not seen to be particularly associated with the openings of the parasomal sac, when seen in several sections, nor in the area of the sac generally, nor did there appear to be any flow of antigen from this area. It was noticed on examining the micrographs that the density of individual ferritin granules and their distance from the pellicular membrane varied greatly. This was also noted in the micrographs of ferritin labelling by Morgan, Rifkind \& Rose (1962). Both these observations could be due to the thickness of the sections, and the fact that the membrane was not perpendicular to the plane of section, particularly when there was a protuberance of the surface, as often occurs on cilia (Pl. 1, fig. 1). Also, the ferritin granules were seldom very close to the membranes; this was possibly due to the fact that the ferritin label might be situated on the globulin at a distance from the active site which combined with the antigen. The varying distances might then be due to the antibody molecule either being attached to antigen by both terminal active sites, or opening out and attaching to antigen by only one end (Lafferty \& Oertelis, 1963; Feinstein \& Rowe, 1965).

At the degree of sensitivity of the fluorescent labelling method it was shown previously (Beale \& Mott, 1962) that the immobilization antigen was not present in the interior cytoplasm of the organism. However, this method is not so sensitive as ferritin labelling so that it is possible that extremely small amounts of antigen in the cytoplasm might be undetected by the fluorescence technique. The presence of a small number of antigen molecules in the internal cytoplasm has therefore not been disproved and thus the immobilization antigen might be formed either in the internal cytoplasm or on the surface membranes. If the antigen is formed in the cytoplasm, antigen molecules would then have to pass to the exterior of the paramecium. The purified soluble immobilization antigens have been studied in some detail and have been subjected to various immunological, chromatographic and electrophoretic tests. The antigens are proteins of molecular weight about 250,000 (Preer, 1959; Bishop, 1961). It would appear that the immobilization antigens might be synthesized on the ribosomes in the cytoplasm, where they could exist as formed antigen molecules, not necessarily very many at any one time, and as such pass out of the cell. These ribosomes might be associated with the membranes of the endoplasmic reticulum (Palade, 1956) which are known to be sites of active synthesis. Ribosomes are also present on the cytoplasmic side of external cell membranes and the antigen could thus be formed close to the cell surface. If the antigen itself is formed on the 
ribosomes, internal ferritin labelling might show antigen associated with polyribosomes made up of a definite number of ribosomes, since various classes of polysomes appear to synthesize similar polypeptide chains as shown in specialized cells such as reticulocytes, making a single protein (Marks, Burka, Rifkind \& Danon, 1963; Rich, Warner \& Goodman, 1963). The alternative to the antigen being synthesized within the cell and moving outside it, is that the information only, as messenger RNA, passes from the gene to the external membranes and the antigen is synthesized there. There is the possibility that this RNA could take the form of an intermediate particle located in the cytoplasm, similar to the metagons in the killer system in paramecium (Gibson \& Beale, 1963). The fibrils, both in the cilia and in the cytoplasmic network, are also known to have enzymic activity (Nelson, 1959); Pitelka (1963) suggested they might transmit information or messenger substances. These systems would necessitate either the antigen protein or the RNA, both molecules of

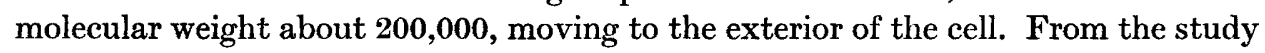
of the ultrastructure, it appears this passage might be possible, not through openings such as pores or the parasomal sac, but through the membranes themselves. If the membranes were static structural entities, there would seem to be several mechanical barriers to a large molecule passing to the exterior. Three ' 3 -ply' membranes and the large peribasal space separate most of the cytoplasm from the exterior, as well as the dense homogeneous layer or membrane mentioned earlier. This dense layer also appears to be continuous with the septum across the base of the cilium, which would appear to be a barrier from the general cytoplasm to the interior of the cilia. It is well known, however, that membranes contain enzymes and that there is a flow of molecules through cell surfaces in metabolism. It is thought that the cell membranes are impermeable to a great many substances unless metabolized by the enzymes in and behind the membranes (Mitchell \& Moyle, 1959). This membraneselective chemical mechanism of Davson \& Danielli (1952) might account for the passage of large molecules, such as antigen or RNA, through the membranes to the exterior, whereas other molecules, such as the globulin of the antibody (of molecular weight 156,000 ) were unable to penetrate the cell-wall, possibly because of the lack of suitable enzymes in the membranes. Mechanical transport through pores in the membranes would not give this degree of specificity. It is possible that these enzymes take part in the transport of special molecules by the formation and dissolution of the membranes which are in a constant state of flux and transformation. It has been suggested for the cytomembranes (Novikoff, Essret, Goldfischer \& Heus, 1962) that they have functional rather than structural continuity, although they are thought to be more or less continuous with the nuclear membrane and possibly also the cell surface (Palade, 1956; Gray, 1964), the surface also being capable of active transformation and vesiculation (Bennett, 1956). Direct observation of the antigen molecules on the membranes is suggested by the fact that these molecules are probably present in large numbers, as indicated by the thickness of the globulin fuzz and by the simple calculation of the probable number of molecules per unit area of surface. It would appear from the present study that the actual antigen molecules cannot be demonstrated on the membranes with the techniques and magnifications used. The study of the membranes by other techniques and at higher magnifications, in addition to the application of the ferritin-labelling technique to the interior of the organism, may be of value in finding possible sites of synthesis of the immobilization antigens. 
The author wishes to thank: Professor G. H. Beale, F.R.S., for providing the opportunity and encouragement to carry out this work; Miss Margaret M. Perry for her introduction to the techniques of electron microscopy; Dr I. G. Jones for helpful discussion; Dr A. Jurand and Mr A. E. G. Dunn for details of staining techniques; Miss Anne R. Wightman for the prints of the electron micrographs; Mr E. D. Roberts for the preparation of the plates. The work was made possible by a grant from the Medical Research Council.

\section{REFERENCES}

Baxandall, J., Perlmann, P. \& Afzelius, B. A. (1962). A two-layer technique for detecting surface antigens in the sea-urchin egg with ferritin-conjugated antibody. J. Cell Biol. 14, 144.

Beale, G. H. \& Kacser, H. (1957). Studies on the antigens of Paramecium aurelia with the aid of fluorescent antibodies. J. gen. Microbiol. 17, 68.

Beale, G. H. \& Mott, M. R. (1962). Further studies on the antigens of Paramecium aurelia with the aid of fluorescent antibodies. J. gen. Microbiol. 28, 617.

BennetT, H. S. (1956). The concept of membrane flow and membrane vesiculation as mechanisms for active transport and ion pumping. J. biophys. biochem. Cytol. 2 (suppl.), 99.

Bishop, J. (1961). Purification of an immobilization antigen of Paramecium aurelia, variety 1. Biochim. biophys. Acta, 50, 471 .

Caulfield, J. B. (1957). Effects of varying the vehicle for $\mathrm{O}_{5} \mathrm{O}_{4}$ in tissue fixation. $J$. biophys. biochem. Cytol. 3, 827.

Chadwick, C. S., McEntegart, M. G. \& NaIrN, R. C. (1958). Fluorescent protein tracers: a trial of new fluorochromes and the development of an alternative to fluorescein. Immunology, $1,315$.

Coons, A. H. (1956). Histochemistry with labelled antibody. Int. Rev. Cytol. 5, I.

Coons, A. H. \& KaPLAN, M. H. (1950). Localization of antigen in tissue cells. II. Improvements in a method for the detection of antigen by means of fluorescent antibody. J. exp. Med. 91, 1.

Davson, H. \& Danielli, J. F. (1952). Permeability of Natural Membranes, 3rd edn. Cambridge University Press.

Ehret, C. F. \& Powers, E. L. (1959). The cell surface of Paramecium. Int. Rev. Cytol. 8, 97.

Feinstein, A. \& Rowe, A. J. (1965). Molecular mechanism of formation of an antigenantibody complex. Nature, Lond. 205, 147.

Gibson, I. \& Beale, G. H. (1963). The action of ribonuclease and 8-azaquanine on matekiller paramecia. Genet. Res., Camb. 4, 42.

Glauert, A. M. \& Glauert, R. H. (1958). Araldite as an embedding medium for electron microscopy. J. biophys. biochem. Cytol. 4, 191.

Gray, E. G. (1964). Electron microscopy of the cell surface. Endeavour, 23, 61 .

LafFErTy, K. J. \& Oertelis, S. (1963). The interaction between virus and antibody. III. Examination of virus-antibody complexes with the electron microscope. Virology, $21,91$.

LAWN, A. M. (1960). The use of potassium permanganate as an electron-dense stain for sections of tissue embedded in epoxy resin. J. biophys. biochem. Cytol. 7, 197.

LEDUC, E. H. \& BERNHARD, W. (1962). Water-soluble embedding media for ultra-structural cytochemistry. Symp. Int. Soc. Cell Biol. 1, 21. New York: Academic Press.

LuFT, J. H. (1961). Improvements in epoxy resin embedding methods. J. biophys. biochem. Cytol. 9, 409.

Marks, P. A., Burka, E. R., Rifkind, R. \& Danon, D. (1963). Polyribosomes active in reticulocyte protein synthesis. Cold Spring Harb. Symp. quant. Biol. 28, 223.

Marshatl, J. D., Eveland, W. C. \& Smith, C. W. (1958). Superiority of fluorescein isothiocyanate (Riggs) for fluorescent-antibody technique with a modification of its application. Proc. Soc. exp. Biol. Med. 98, 898. 
Mitcheld, P. \& Moyze, J. (1959). Coupling of metabolism and transport by enzymic translocation of substrates through membranes. Proc. R. phys. Soc. Edinb. $28,19$.

Morgan, C., Rifkind, R. A. \& Rose, H. M. (1962). The use of ferritin-conjugated antibodies in electron microscopic studies of influenza and vaccinia viruses. Cold Spring Harb. Symp. quant. Biol. 27, 57.

MotT, M. R. (1963). Cytochemical localization of antigens of Paramecium by ferritinconjugated antibody and by counterstaining of the resultant absorbed globulin. $J . R$. Micr. Soc. 81, 159.

Nelson, L. (1959). Cytochemical studies with the electron microscope. II. Succinic dehydrogenase in rat spermatozoa. Exp. Cell Res. 16, 403.

Novikoff, A. B., Eissner, E., Goldfischer, S. \& Heus, M. (1962). Nucleosidephosphatase activities of cytomembranes. Symp. Int. Soc. Cell Biol. 1, 149. New York: Academic Press.

Palade, G. E. (1952). A study of fixation for electron microscopy. J. exp. Med. 95, 285.

Palade, G. E. (1956). The endoplasmic reticulum. J. biophys. biochem. Cytol. 2 (Suppl.), 85.

Pitelka, D. R. (1961). Fine structure of the silverline and fibrillar systems of three tetrahymenid ciliates. J. Protozool. 8, 75.

Prtelka, D. R. (1963). Electron-Microscopic Structure of Protozoa. London: Pergamon Press.

Preer, J. R. (1959). Studies on the immobilization antigens of Paramecium. III. Properties. J. Immunol. 83, 385.

Rich, A., Warner, J. R. \& Goodman, H. M. (1963). The structure and function of polyribosomes. Cold Spring Harb. Symp. quant. Biol. 28, 269.

RoBertson, J. D. (1960). The molecular structure and contact relationships of cell membranes. Prog. Biophys. 10, 344.

Singer, S. J. (1959). Preparation of an electron-dense antibody conjugate. Nature, Lond. $183,1523$.

Singer, S. J. \& Schick, A. F. (1961). The properties of specific stains for electron microscopy prepared by the conjugation of antibody molecules with ferritin. $J$. biophys. biochem. Cytol. 9, 519.

Sonnebonn, T. M. (1950). Methods in the general biology and genetics of Paramecium aurelia. J. exp. Zool. 113, 87.

SPENDlove, R. S. \& Singer, S. J. (1961). On the preservation of antigenic determinants during fixation and embedding for electron microscopy. Proc. natn. Acad. Sci., U.S.A. 47, 14.

Staubli, W. C. R. (1960). Nouvelle matière d'inclusion hydrosoluble pour la cytologie électronique. C. r. hebd. Séanc. Acad. Sci., Paris, 250, 1137.

Stewart, J. M. \& Muir, A. R. (1963). The fine structure of the cortial layers in Paramecium aurelia. Quart. J. micr. Sci. 104, 129.

Stokckenius, W. (1962). The molecular structure of lipid-water systems and cell membrane models studied with the electron microscope. Symp. Int. Soc. Cell Biol. 1, 349. New York: Academic Press.

Watson, M. L. (1958). Staining of tissue sections for electron microscopy with heavy metals. J. biophys. biochem. Cytol. 4, 475. 


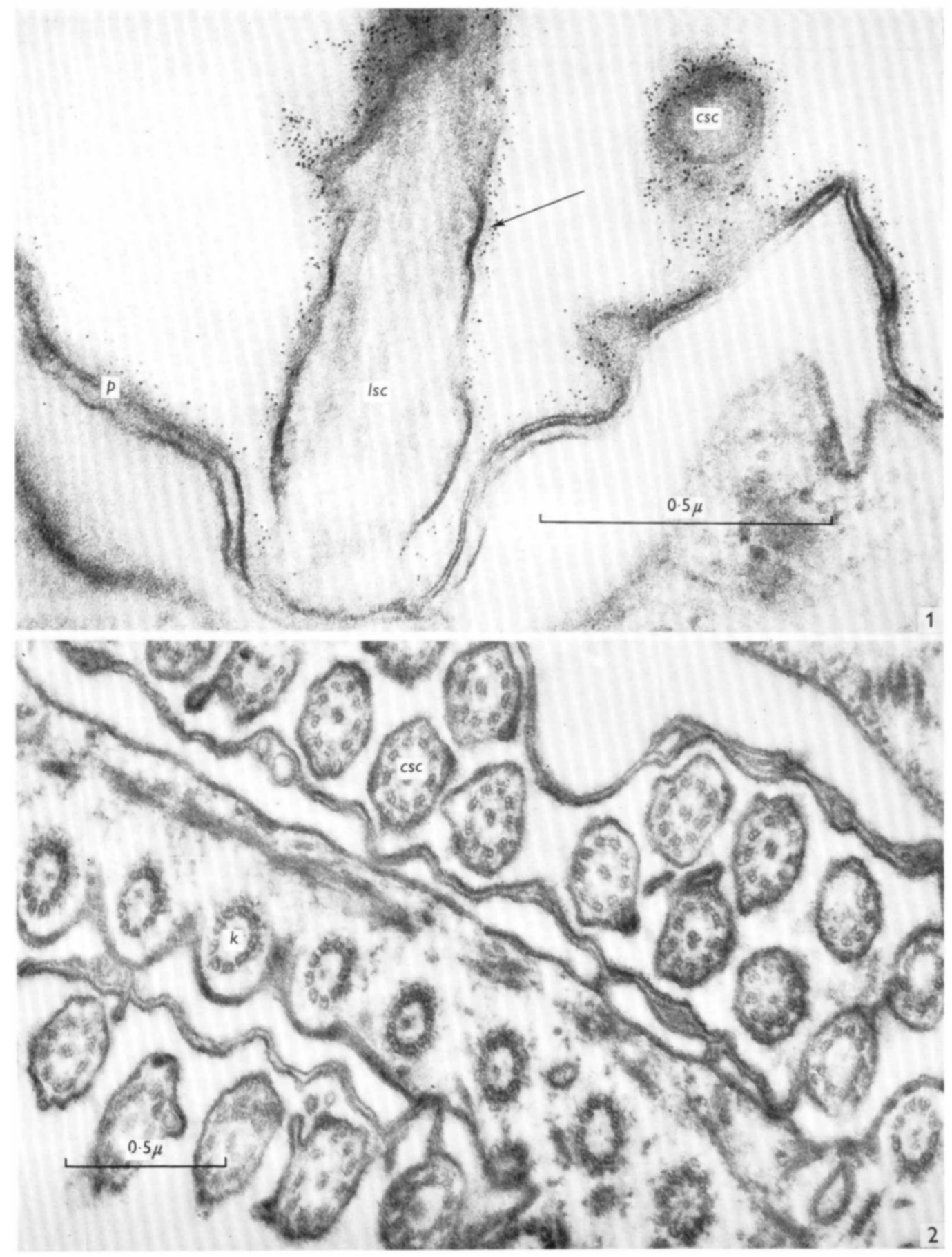

M. R. MOTT

(Facing p. 260) 
Journal of General Microbiology, Vol. 41, No. 2

Plate 2

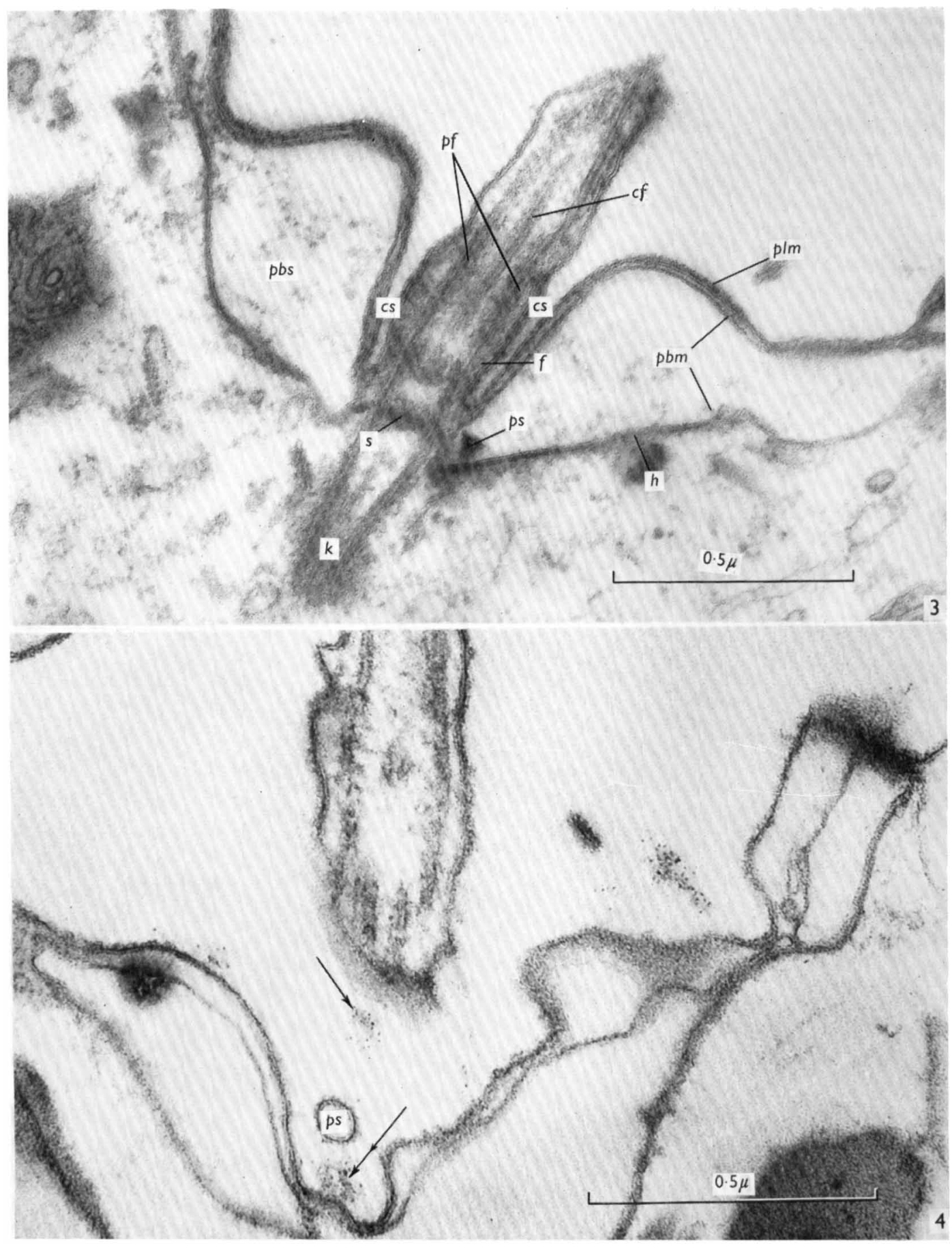

M. R. MOT'T 


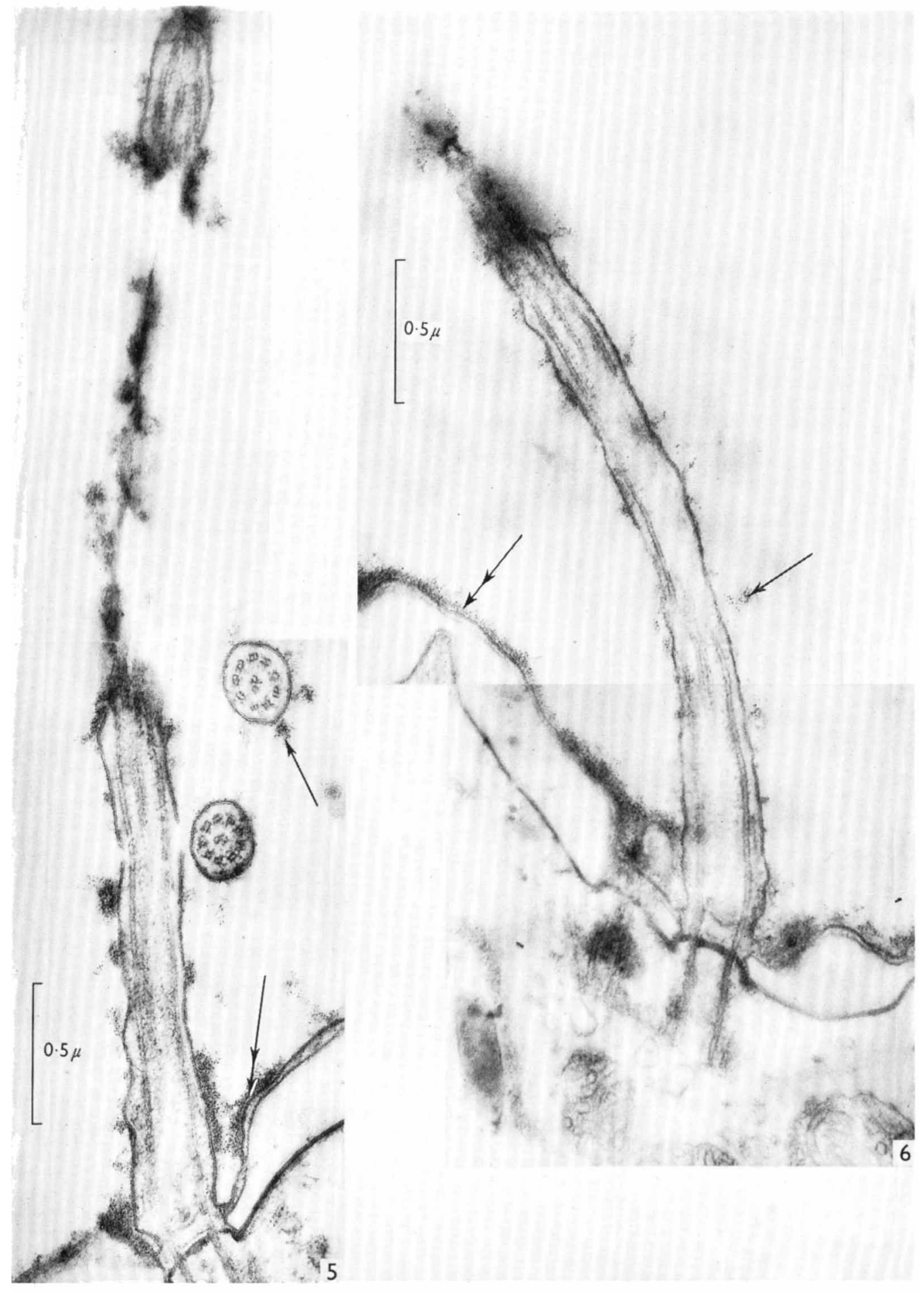

M. R. MOTT 



\section{EXPLANATION OF PLA'TES}

Key to plates. $c f=$ central fibrils; $c s=$ circumciliary space; $c s c=$ cross-section of cilium; $f=$ fold; $h=$ homogeneous layer; $k=$ kinetosome; $l s c=$ longitudinal section of cilium; $p=$ pellicle; $p b m=$ peribasal membrane; $p b s=$ peribasal space; $p f=$ peripheral fibrils; $p l m=$ pellicular membrane; $p s=$ portion of parasomal sac $; s=$ septum.

\section{Plate 1}

Fig. 1. Unstained section of cilium of a Paramecium fixed and treated with ferritin-labelled homologous antibody, showing ferritin granules (arrow) on pellicle and cilium. Note poor structural detail in this unstained section.

Fig. 2. Counterstained section of gullet area of an homologous paramecium fixed and treated with ferritin-labelled antibody, showing the usual ' 3 -ply' membranes and no globulin fuzz or ferritin granules in this area. Cross-sections of cilia and kinetosomes are seen.

\section{Plates 2 and 3}

Comparisons of counterstained sections of fixed paramecia treated with ferritin-labelled antibody to the 'new' antigen being formed during antigenic transformation.

\section{Plate 2}

Fig. 3. At the beginning of the transformation experiment, after 'nil hours' growth at $35^{\circ}$. No fuzz or ferritin granules are present on the surface of either pellicle or cilium. Note single ' 3 -ply' membrane around the cilium, and the double '3-ply' membrane over the pellicle. (Reproduced by kind permission of the Royal Microscopical Society from the report of the proceedings of the Symposium on Cytochemical Progress in Electron Microscopy, Oxford, 1962. Published in the J. R. Micr. Soc. 81, 1963.)

Fig. 4. After $1 \mathrm{hr}$ of growth at $35^{\circ}$, showing very few isolated sites of ferritin granules and faint globulin fuzz on pellicle (double arrow) and cilia (arrow). The possible opening of the parasomal sac is seen below the cilium.

\section{Plate 3}

Fig. 5. After growth for $6 \mathrm{hr}$ at $\mathbf{3 5}^{\circ}$. The globulin fuzz and ferritin granules can be seen at a large number of separate sites on the pellicle (double arrow) and also on the longitudinal and crosssections of the cilia (arrow).

Fig. 6. After growth for $7 \mathrm{hr}$ at $35^{\circ}$. The globulin fuzz and ferritin granules are seen to cover the entire pellicle (double arrow), but are still in isolated sites on the cilium (arrow). 